\title{
Synthesis and Mechanism of Tetracalcium Phosphate from Nanocrystalline Precursor
}

\author{
Jianguo Liao,, Xingze Duan, ${ }^{1}$ Yanqun Li, ${ }^{1}$ Caifeng Zheng, ${ }^{2}$ Zhengpeng Yang, \\ Aiguo Zhou, ${ }^{1}$ and Dinghua Zou ${ }^{1}$ \\ ${ }^{1}$ School of Materials Science and Engineering, Cultivating Base for Key Laboratory of Environment-Friendly Inorganic Materials in \\ University of Henan Province, Henan Polytechnic University, Jiaozuo 454000, China \\ ${ }^{2}$ Carbon/Carbon Composites Technology Research Center, Northwestern Polytechnical University, Xian 710072, China
}

Correspondence should be addressed to Jianguo Liao; liaojianguo10@hpu.edu.cn

Received 23 July 2014; Revised 17 October 2014; Accepted 17 October 2014; Published 11 November 2014

Academic Editor: Christian Brosseau

Copyright (C) 2014 Jianguo Liao et al. This is an open access article distributed under the Creative Commons Attribution License, which permits unrestricted use, distribution, and reproduction in any medium, provided the original work is properly cited.

\begin{abstract}
Tetracalcium phosphate (TTCP, $\left.\mathrm{Ca}_{4}\left(\mathrm{PO}_{4}\right)_{2} \mathrm{O}\right)$ was prepared by the calcination of coprecipitated mixture of nanoscale hydroxyapatite $\left(\mathrm{HA}, \mathrm{Ca}_{10}\left(\mathrm{PO}_{4}\right)_{6}(\mathrm{OH})_{2}\right)$ and calcium carbonate crystal $\left(\mathrm{CaCO}_{3}\right)$, followed by cooling in the air or furnace. The effect of calcination temperature on crystal structure and phase composition of the coprecipitation mixture was characterized by transmission electron microscope (TEM), thermal analysis-thermogravimetry (DTA-TG), X-ray diffraction (XRD), Fourier transform-infrared spectroscopy (FT-IR), and Raman spectroscopy (RS). The obtained results indicated that the synthesized mixture consisted of nanoscale $\mathrm{HA}$ and $\mathrm{CaCO}_{3}$ with uniform distribution throughout the composite. TTCP was observed in the air quenching samples when the calcination temperature was above $1185^{\circ} \mathrm{C}$. With the increase of the calcination temperature, the amount of the intermediate products in the air quenching samples decreased and cannot be detected when calcination temperature reached $1450^{\circ} \mathrm{C}$. Unexpectedly, the mixture of HA and calcium oxide was observed in the furnace cooling samples. Clearly, the calcination temperature and cooling methods are critical for the synthesis of high-purity TTCP. The results indicate that the nanosize of precursors can decrease the calcination temperature, and TTCP can be calcinated by low temperature.
\end{abstract}

\section{Introduction}

Monoclinic tetracalcium phosphate $\left(\mathrm{CaO}\left(\mathrm{PO}_{4}\right)_{2}\right.$, TTCP), a kind of calcium phosphates which can be formed in the $\left(\mathrm{CaO}-\mathrm{P}_{2} \mathrm{O}_{5}\right)$ system at high temperature $\left(>1300^{\circ} \mathrm{C}\right)$, is the only calcium phosphate phase with a $\mathrm{Ca} / \mathrm{P}$ ratio greater than stoichiometric hydroxyapatite $\left(\mathrm{Ca}_{10}\left(\mathrm{PO}_{4}\right)_{6}(\mathrm{OH})_{2}, \mathrm{HA}\right)$. It shows moderate reactivity and solubility when combined with acidic calcium phosphates such as dicalcium phosphate anhydrous $\left(\mathrm{CaHPO}_{4}, \mathrm{DCPA}\right.$, monetite) or dicalcium phosphate dihydrate $\left(\mathrm{CaHPO}_{4} \cdot 2 \mathrm{H}_{2} \mathrm{O}, \mathrm{DCPD}\right.$, brushite). Therefore, TTCP has been widely used in self-setting calcium phosphate cements for bone regeneration, which consequently leads to the formation of HA in physiologic conditions [1-4].

The preparation of high-purity TTCP powders, an important raw material in the field of calcium phosphate bone cements, is the key to fabricate calcium phosphate bone cements (CPC) with desirable performance in vivo.
Regarding the synthesis of TTCP, there are mainly two approaches. One is direct solid-state reaction and the other is wet process reaction. The solid-state reaction at high temperature has been widely used in the synthesis of TTCP [5-7]. This technique is usually based on the use of mixtures of calcium carbonate $\left(\mathrm{CaCO}_{3}\right)$ and dicalcium phosphate anhydrate $\left(\mathrm{CaHPO}_{4}\right)(\mathrm{Ca} / \mathrm{P}$ ratio of 2$)$, followed by heating at $1450-1500^{\circ} \mathrm{C}$ for $6-12 \mathrm{~h}$. However, the treatment time of this method is long and the obtained products are generally not pure, including other phases such as calcium phosphates and even calcium oxide [8-11]. Dai et al. [12] have prepared the $\mathrm{HA}$ and $\mathrm{CaO}$ doped TTCP by this method. On the other hand, wet process reaction mainly refers to coprecipitationsolid state reaction. The nanoscale hydroxyapatite-calcium carbonate powder mixture was firstly prepared by the coprecipitation, followed by calcination at $1500^{\circ} \mathrm{C}$ to obtain TTCP. In this way, high purity TTCP can be obtained at low 
temperature by this time-saving and facile method which most likely resulted from the small dimension effect and surface effect of precipitated nanoparticles. In this study, we present a modified method for the preparation of pure TTCP based on nanosized powder mixtures of the calcium carbonate and hydroxyapatite by wet process reaction and then calcinated at different temperature. The phase transition resulting from the synthesizing process of TTCP was investigated by TEM, DTA-TG, XRD, FT-IR, and RS. The reaction mechanism was explored, and the optimal temperature for synthesis of TTCP ceramics with high purity was obtained.

\section{Materials and Methods}

2.1. Preparation of Sample. Calcium nitrate (Ca $\left(\mathrm{NO}_{3}\right)_{2} \cdot 4 \mathrm{H}_{2} \mathrm{O}$ ) (Shanghai ShanPu Chemical Reagent Co., Ltd., China), diammonium hydrogen phosphate $\left(\left(\mathrm{NH}_{4}\right)_{2} \mathrm{HPO}_{4}\right)$ (Tianjin Dengke Chemical Reagent Co. Ltd., China), ammonium carbonate $\left(\left(\mathrm{NH}_{4}\right)_{2} \mathrm{CO}_{3}\right)$ (Tianjin Kermel Chemical Reagent Co., Ltd., China), and all other reagents used in the present study were of analytical grade.

The $\left(\mathrm{NH}_{4}\right)_{2} \mathrm{HPO}_{4}$ aqueous solution was slowly dropped into the stirred $\mathrm{Ca}\left(\mathrm{NO}_{3}\right)_{2}$ aqueous solution at water bath with the temperature of $60^{\circ} \mathrm{C}$ with a $\mathrm{Ca} / \mathrm{P}$ molar ratio 2 , and the $\mathrm{pH}$ for mature solution was adjusted to $11-12$ by ammonium solution (26-28 vol\%). After stirring for $2 \mathrm{~h}$ and precipitating for $24 \mathrm{~h}$, pump filter was followed by washing 3 times with alcohol and drying in vacuum drier at $90^{\circ} \mathrm{C}$ for $24 \mathrm{~h}$. After that the mixtures of nano-hydroxyapatite (n-HA) and nanocalcium carbonate (nano- $\mathrm{CaCO}_{3}$ ) were acquired. The dried mixture was calcinated at $850^{\circ} \mathrm{C}, 1150^{\circ} \mathrm{C}, 1200^{\circ} \mathrm{C}, 1250^{\circ} \mathrm{C}$, $1300^{\circ} \mathrm{C}, 1350^{\circ} \mathrm{C}, 1400^{\circ} \mathrm{C}, 1450^{\circ} \mathrm{C}$, and $1500^{\circ} \mathrm{C}$ in an alumina crucible with a heating rate of $10^{\circ} \mathrm{C} / \mathrm{min}$ and kept for $8 \mathrm{~h}$. The product was rapidly cooled to room temperature by means of a lifting device in the air (about cooling rate $150^{\circ} \mathrm{C} / \mathrm{min}$ ).

In addition, some mixing powder calcinated at $1400^{\circ} \mathrm{C}$, $1450^{\circ} \mathrm{C}$, and $1500^{\circ} \mathrm{C}$ was cooled to room temperature in the furnace (about cooling rate $1^{\circ} \mathrm{C} / \mathrm{min}$ ).

2.2. Characterization of Sample. The morphology and microstructure of the precipitate mixtures were examined by transmission electron microscopy (TEM, JEM-2100 (URP), Jeol, Japan).

Powder XRD was used for phase analysis of the samples. The analysis was carried out on an X-ray diffractometer (XRD, D8ADVANCE, Bruker, Germany) equipped with a monochromator in the diffracted beam. The diffraction spectra were recorded from $15^{\circ}$ to $60^{\circ}$ using $\mathrm{CuKa}$ (wavelength $=$ $0.154056 \mathrm{~nm}, 40 \mathrm{~mA}, 40 \mathrm{kV}$ ) radiation with step size $0.05^{\circ}$ and step duration $1 \mathrm{~s}$.

DTA-TG was conducted on the as-prepared powders (10 mg) to ascertain the thermal stability and decomposition temperature. DTA-TG was performed using thermal analysis-thermogravimetry (DTA-TG, STA409PC/4/H,

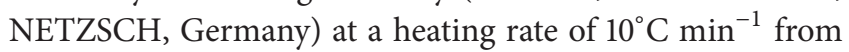
50 to $1500^{\circ} \mathrm{C}$ in a static air atmosphere.

For excitation of Raman spectra the $514.5 \mathrm{~nm}$ line $(20 \mathrm{~mW})$ of an $\mathrm{Ar}^{+}$-ion laser (inVia-Laser microscopic confocal Raman spectroscopy, Renishaw, UK) was used with resolution of $1 \mathrm{~cm}^{-1}$.

Fourier transformed infrared (FTIR) spectra were recorded from $\mathrm{KBr}$ pellets by means of a Shimadzu-2000 FT-IR spectrometer (FT-IR, Shimadzu 2000, Shimadzu, Japan) with a spectral resolution of $2 \mathrm{~cm}^{-1}$.

\section{Results and Discussion}

3.1. TEM Analysis. Figure 1(a) is the TEM images of synthesized nanocrystals and Figures $1(\mathrm{~b})$ and $1(\mathrm{c})$ are the corresponding selected area electron diffraction analysis. It can be seen that the synthesized mixtures were nanosized rodlike crystals of calcium carbonate with size of $2-4 \mathrm{~nm}$ in diameter and $30-40 \mathrm{~nm}$ in length with an aspect ratio of $\sim 12$. Needle-like crystals of poorly crystallized hydroxyapatite were also observed with crystal size of $10-20 \mathrm{~nm}$ in diameter by $40-60 \mathrm{~nm}$ in length with an aspect ratio of $\sim 3$. n-HA and nano- $\mathrm{CaCO}_{3}$ diffraction patterns were tested by selected area electron diffraction (SAED) as shown in Figures 1(b) and $1(\mathrm{c})$. Electron diffraction patterns were made of different radius of concentric circles, which clearly indicated that the substance was slightly crystallized crystal. The electron diffraction pattern composition was further determined by calculation of interplanar spacing based on

$$
d=\frac{K}{R}
$$

where $d$ is the crystal interplanar distance, $K$ is the camera constant, and $R$ is radius of diffractions rings. By comparing the calculated interplanar distance with standard PDF CARDS, it was confirmed that the synthetic crystals were composed of n-HA and n-CC. The corresponding (HKL) value of diffraction rings has been marked in Figures 1(b) and $1(\mathrm{c})$.

3.2. Thermal Analysis. Figure 2 shows the TG-DTA diagram of synthesized samples. It was observed that the weight loss was about $5.5 \%$ when the temperature changed from room temperature to $230^{\circ} \mathrm{C}$, mainly caused by the loss of adsorbed water in the sample. Lattice water of the samples was removed in the temperature range of $230-570^{\circ} \mathrm{C}$ and the weight loss was shown to be about $2.5 \% \cdot \mathrm{CaCO}_{3}$ was decomposed (equation (2)) in the temperature range of $570-850^{\circ} \mathrm{C}$ and weight loss was about $4.59 \%$. In the range of $850-1185^{\circ} \mathrm{C}$, the nonstoichiometric HA was decomposed into $\beta$-tricalcium phosphate $\left(\beta-\mathrm{Ca}_{3}\left(\mathrm{PO}_{4}\right)_{2}, \beta\right.$-TCP) and HA (equation (3)) [13]. While the temperature exceeded $850^{\circ} \mathrm{C}$, HA could react to form oxygen apatite $\left(\mathrm{Ca}_{10}\left(\mathrm{PO}_{4}\right)_{6}(\mathrm{OH})_{2-2 x} \mathrm{O}_{x} \square_{x}\right.$, OHA) (equation (4)) $[13,14]$. When reaction temperature was above $1050^{\circ} \mathrm{C}, \mathrm{Ca}_{10}\left(\mathrm{PO}_{4}\right)_{6}(\mathrm{OH})_{2}$ could react to form $\beta$-TCP and TTCP (equation (5)) [13]; while the temperature exceeded $1350^{\circ} \mathrm{C}, \beta$-TCP could transform into $\alpha$-tricalcium phosphate $\left(\alpha-\mathrm{Ca}_{3}\left(\mathrm{PO}_{4}\right)_{2}, \alpha\right.$-TCP) (equation (6)) [13]; meanwhile, the $\beta$-TCP and HA were formed by the reaction as shown in (3), which could also react to form $\alpha$-TCP and TTCP in the temperature range of $1185-1255^{\circ} \mathrm{C}$ (equation (7)) [13]. Moreover, when the enough $\mathrm{CaO}$ existed in the calcination 


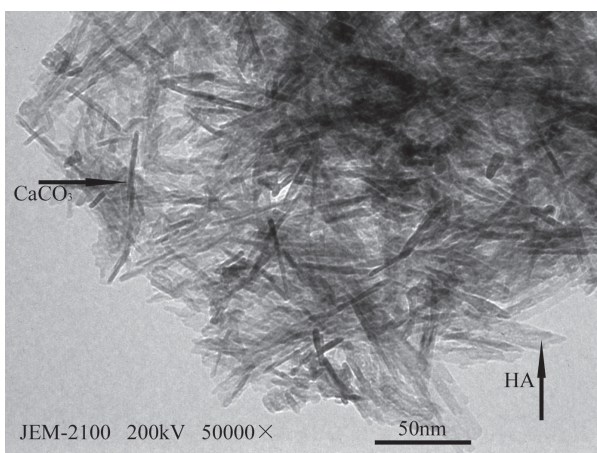

(a)

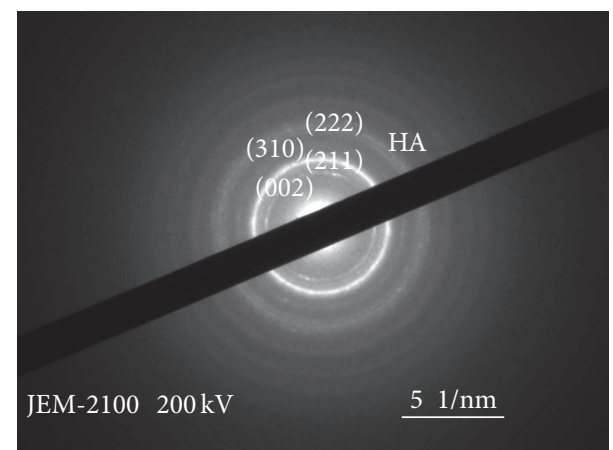

(b)

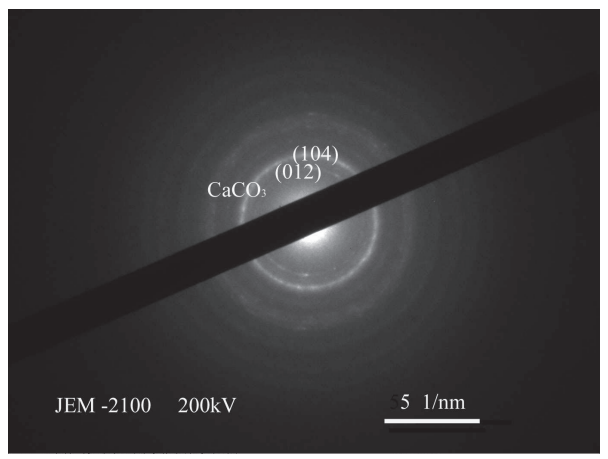

(c)

FIGURE 1: TEM images of the precipitates (a) and the selected area electron diffraction analysis (b, c).

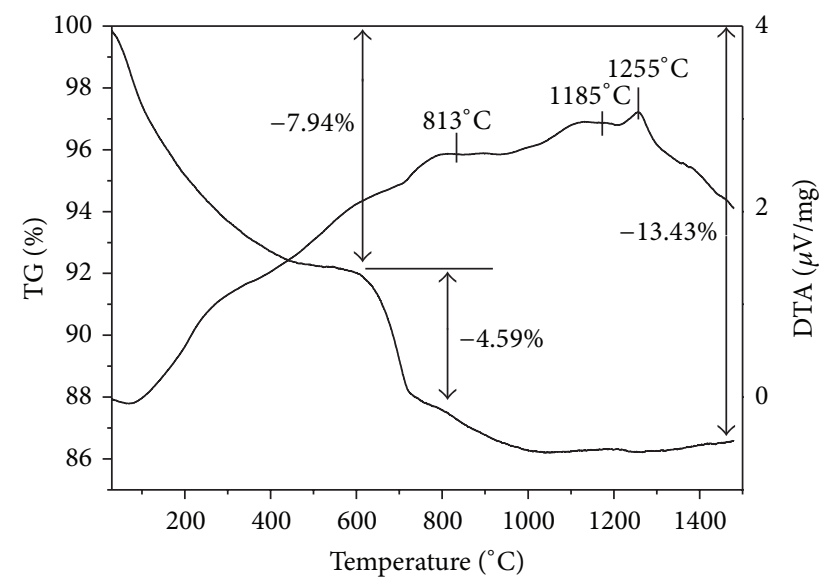

FIGURE 2: TG and DTA curves of synthetic sample.

samples, the final products TTCP could be formed by reaction shown in (8) and $(9)[11,13]$. Consider the following:

$$
\mathrm{CaCO}_{3} \longrightarrow \mathrm{CaO}+\mathrm{CO}_{2}
$$

nonstoichiometric HA

$$
\begin{aligned}
\mathrm{Ca}_{10-x} \mathrm{H}_{2 x}\left(\mathrm{PO}_{4}\right)_{6}(\mathrm{OH})_{2} \stackrel{>800^{\circ} \mathrm{C}}{\longrightarrow} & \beta-\mathrm{Ca}_{3}\left(\mathrm{PO}_{4}\right)_{2} \\
& +\mathrm{Ca}_{10}\left(\mathrm{PO}_{4}\right)_{6}(\mathrm{OH})_{2}
\end{aligned}
$$

and stoichiometric HA

$$
\begin{gathered}
\mathrm{Ca}_{10}\left(\mathrm{PO}_{4}\right)_{6}(\mathrm{OH})_{2} \stackrel{>850^{\circ} \mathrm{C}}{\longrightarrow} \mathrm{Ca}_{10}\left(\mathrm{PO}_{4}\right)_{6}(\mathrm{OH})_{2-2 x} \mathrm{O}_{x} \square_{x} \\
\mathrm{Ca}_{10}\left(\mathrm{PO}_{4}\right)_{6}(\mathrm{OH})_{2-2 x} \mathrm{O}_{x} \square_{x} \stackrel{>1050^{\circ} \mathrm{C}}{\longrightarrow} 2 \beta-\mathrm{Ca}_{3}\left(\mathrm{PO}_{4}\right)_{2} \\
+\mathrm{Ca}_{4} \mathrm{O}\left(\mathrm{PO}_{4}\right)_{2}
\end{gathered}
$$

3.3. XRD Analysis. Figure 3 shows the XRD patterns of the air-cooled quenching products sintered at different temperatures. It can be seen from Figures 3(a) and 3(b) that coprecipitation products were mainly composed of $\mathrm{HA}$ and calcium carbonate $\left(\mathrm{CaCO}_{3}\right)$, as evidenced by the characteristic peaks of HA (JCPDS-09-0432) at $2 \theta=25.9^{\circ}(002), 31.9^{\circ}(211)$, $32.3^{\circ}(112), 32.9^{\circ}(300), 39.9^{\circ}(310)$ and the characteristic peak 


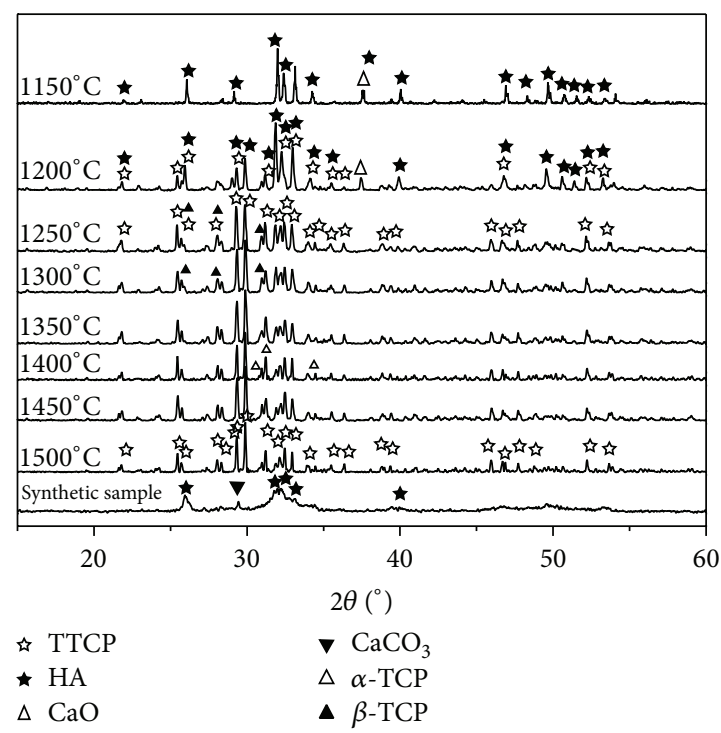

(a)

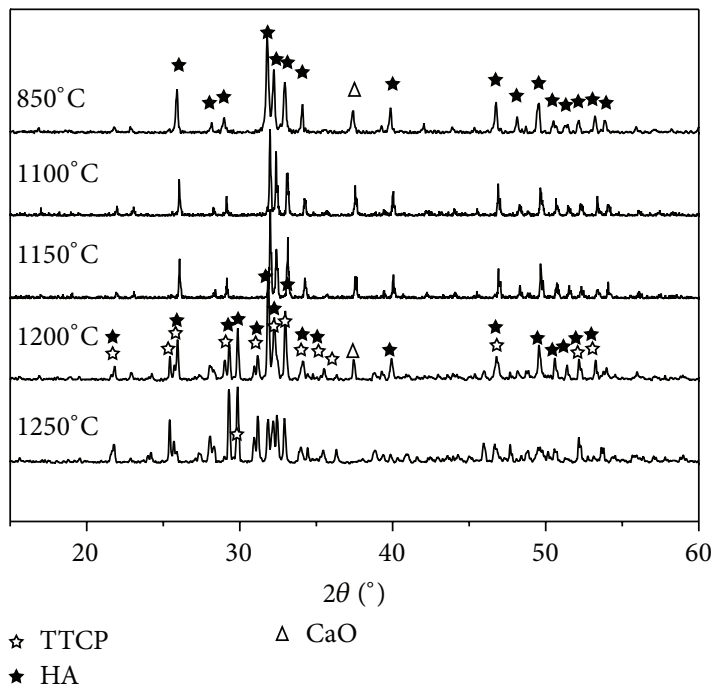

(c)

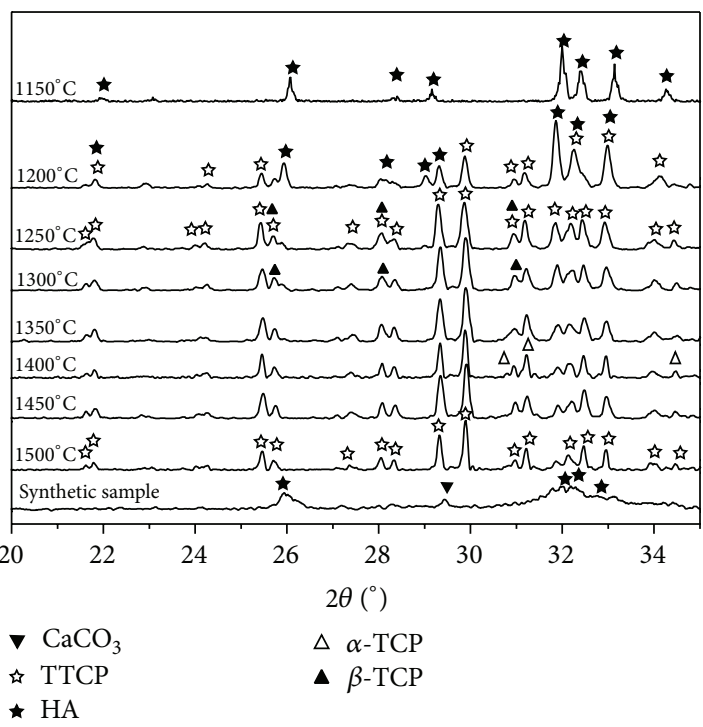

(b)

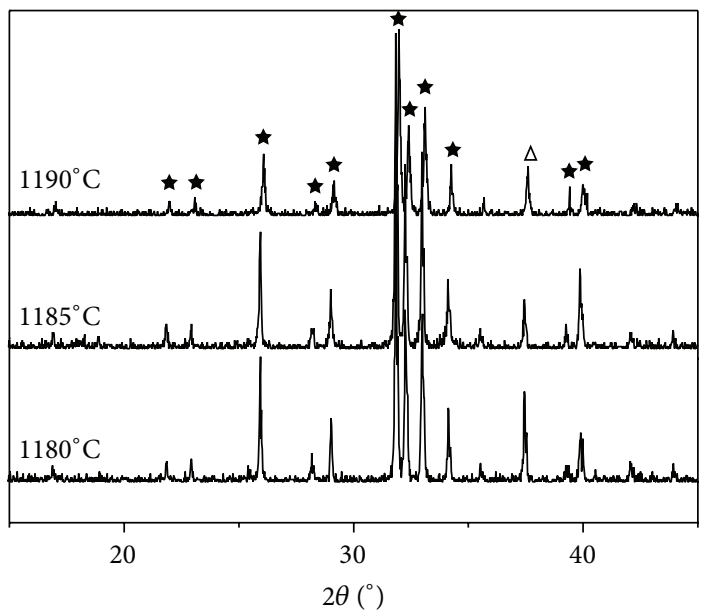

$\star \mathrm{HA}$

$\Delta \mathrm{CaO}$

(d)

FIGURE 3: XRD patterns of synthetic samples after air-cooled quenching at various temperatures: full patterns $\left(\mathrm{a}, \mathrm{c} 2 \theta=15-60^{\circ}\right)$ and partial patterns (b $2 \theta=20-35^{\circ}, \mathrm{d} 2 \theta=15-45^{\circ}$ ), (a) synthetic sample, after air-cooled quenching at $1150-1500^{\circ} \mathrm{C}$ for $8 \mathrm{~h}$, (b) partial patterns of (a), (c) after air-cooled quenching at $850^{\circ} \mathrm{C}, 1100^{\circ} \mathrm{C}, 1150^{\circ} \mathrm{C}, 1200^{\circ} \mathrm{C}$, and $1250^{\circ} \mathrm{C}$ for $8 \mathrm{~h},(\mathrm{~d})$ after air-cooled quenching at $1180^{\circ} \mathrm{C}, 1185^{\circ} \mathrm{C}$, and $1190^{\circ} \mathrm{C}$ for $8 \mathrm{~h}$.

of $\mathrm{CaCO}_{3}$ (JCPDS-29-0305) $\left(2 \theta=29.4^{\circ}(104)\right)$ appearing in the XRD pattern of the samples. Moreover, the broad diffraction peaks revealed that both $\mathrm{HA}$ and $\mathrm{CaCO}_{3}$ were poorly crystallized. After the calcination of coprecipitation products at $850^{\circ} \mathrm{C}, 1100^{\circ} \mathrm{C}$, and $1150^{\circ} \mathrm{C}$ for $8 \mathrm{~h}$ (Figure $3(\mathrm{c})$ ), respectively, mainly HA and calcium oxide (CaO, JCPDS-37-1497) remained. The absence of TTCP characteristic peaks indicated that the synthesis reaction of TTCP does not happen in this temperature range. The presence of characteristic peaks of the HA, TTCP, and $\mathrm{CaO}$ after calcination at $1200^{\circ} \mathrm{C}$ for $8 \mathrm{~h}$ showed that the calcination temperature between $1150^{\circ} \mathrm{C}$ and $1200^{\circ} \mathrm{C}$ resulted into the formation of TTCP phase, which corresponded to the results of DTA analysis, namely, crystal transition of TTCP about $1185^{\circ} \mathrm{C}$. Figure $3(\mathrm{~d})$ shows the XRD patterns of the products calcinated at $1180^{\circ} \mathrm{C}, 1185^{\circ} \mathrm{C}$, and $1190^{\circ} \mathrm{C}$ for $8 \mathrm{~h}$. When the temperature was varied from 1180 to $1185^{\circ} \mathrm{C}$, the peak intensity of $\mathrm{CaO}$ at $2 \theta=37.4^{\circ}(200)$ and $\mathrm{HA}$ at $2 \theta=25.4^{\circ}$ decreased. Such phenomena may be due to the formation of a little amount of TTCP, causing an absence of characteristic peak of TTCP.

If the coprecipitation mixture was calcinated at $1250^{\circ} \mathrm{C}$ to $1500^{\circ} \mathrm{C}$ for $8 \mathrm{~h}$ followed by air-cooling, the characteristic peaks of the resultant products were at $21.8^{\circ}(121), 25.4^{\circ}(200)$, $25.7^{\circ}(130), 28.0^{\circ}(211), 28.3^{\circ}(211), 29.3^{\circ}(032), 29.8^{\circ}(040), 30.9^{\circ}$ $(-103), 31.2^{\circ}(221), 31.9^{\circ}(-132), 32.1^{\circ}(113), 32.4^{\circ}(-212)$, and $32.9^{\circ}(212)$, which agreed with the JCPDS pattern number 


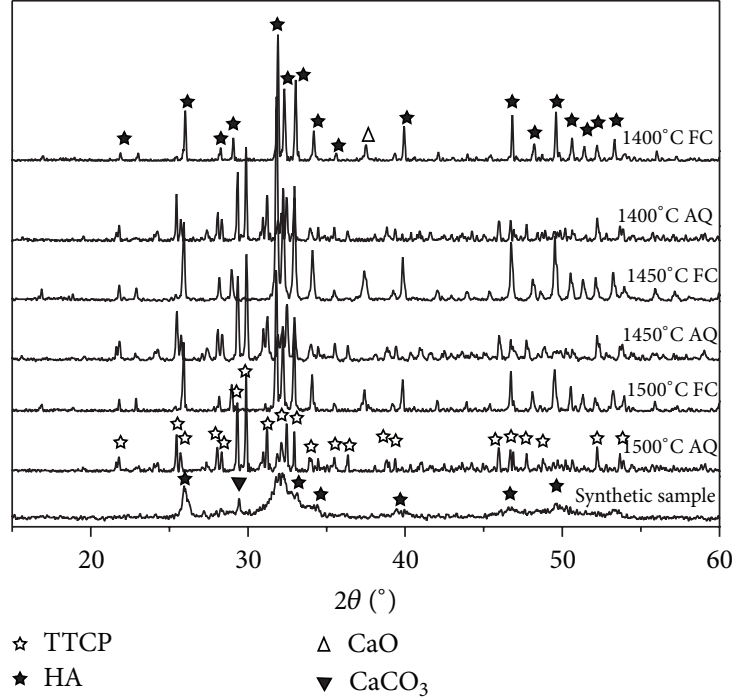

(a)

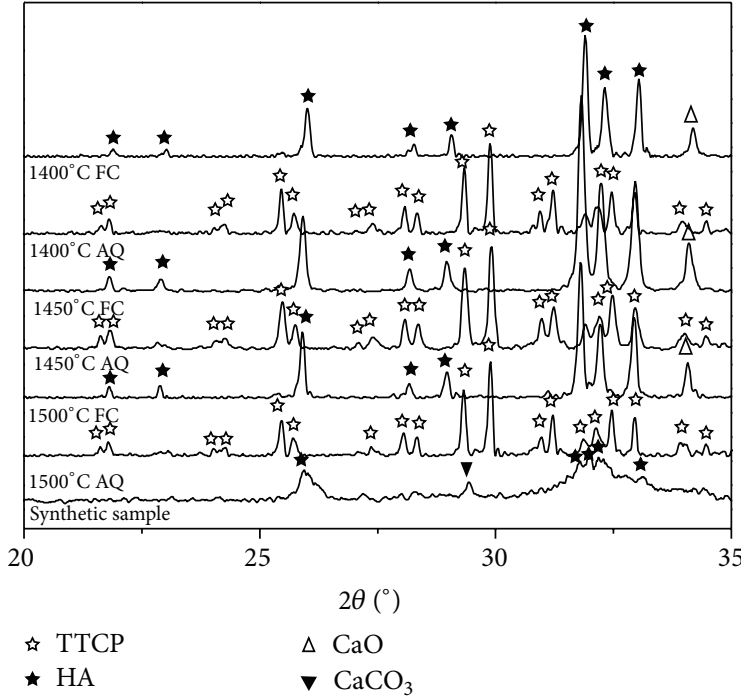

(b)

FIGURE 4: XRD patterns of the calcinations samples by different cooling methods: full patterns (a) and partial patterns (b). AQ indicates air quenching and FC indicates furnace cooling.

25-1137 of TTCP. Meanwhile, the disappearance of $\mathrm{CaO}$ characteristic peaks showed that the high-purity TTCP can be prepared with the temperature rising to more than $1250^{\circ} \mathrm{C}$.

Figure 4 displays XRD patterns of samples by different cooling methods after the high temperature calcination. It was obvious that the furnace-cooled samples exhibited characteristic peak of calcium oxide at ca. $37.5^{\circ}$ [14]; the other characteristic peaks at $25.9^{\circ}, 31.8^{\circ}, 32.2^{\circ}, 32.9^{\circ}, 34.1^{\circ}, 39.8^{\circ}$, $46.7^{\circ}, 48.1^{\circ}, 49.2^{\circ}$, and $49.5^{\circ}$ can be related to the peaks of HA phase. However, the characteristic peaks of TTCP and HA at $2 \theta=31.8^{\circ}, 32.2^{\circ}, 32.9^{\circ}, 32.2^{\circ}, 46.7^{\circ}$, and $48.1^{\circ}$ are relatively similar, which makes it quite difficult to identify the phase composition of this mixture, thereby confirming the previous conclusion that with the furnace cooling method pure TTCP cannot be obtained [15].

3.4. FT-IR Analysis. The fundamental vibration modes for the isolated $\mathrm{PO}_{4}{ }^{3-}$ ion are designated as $v_{1}, v_{2}, v_{3}$, and $v_{4}$. Vibrations from the symmetric stretching motion of the P$\mathrm{O}$ bonds corresponded to $v_{1}$, while the bending vibrations corresponded to $v_{2}$. The wavenumber of asymmetric stretching vibrations was represented as $\nu_{3}$ and the wavenumber of $\mathrm{O}-\mathrm{P}-\mathrm{O}$ asymmetric bending vibrations was represented as $\nu_{4}$ $[16,17]$.

Figure 5 shows the FT-IR spectra of the calcinated and air-cooled products. The peaks at $603 \mathrm{~cm}^{-1}$ and $567 \mathrm{~cm}^{-1}\left(\nu_{4}\right)$ were assigned to the asymmetric bending vibration of $\mathrm{PO}_{4}{ }^{3-}$ group in HA, the peaks at $1037 \mathrm{~cm}^{-1}$ and $1092 \mathrm{~cm}^{-1}\left(\nu_{3}\right)$ was related to the antisymmetry stretching vibration of $\mathrm{PO}_{4}{ }^{3-}$ group, and and the peak at $962 \mathrm{~cm}^{-1}\left(\nu_{1}\right)$ represented the symmetry stretching vibration of $\mathrm{PO}_{4}{ }^{3-}$ group. The stretching and bending vibrations of $\mathrm{OH}^{-}$groups in $\mathrm{HA}$ appeared at about $3572 \mathrm{~cm}^{-1}$ and $635 \mathrm{~cm}^{-1}$. Thus, the characteristics vibrations of $\mathrm{PO}_{4}{ }^{3-}$ and $\mathrm{OH}^{-}$indicated that $\mathrm{HA}$ existed in the synthetic sample. Peaks at $1637 \mathrm{~cm}^{-1}$ and $3431 \mathrm{~cm}^{-1}$ belonged to bending vibration and stretching vibration of surface adsorbed water in the synthetic sample, respectively. Peaks at $1386 \mathrm{~cm}^{-1}$ belonged to antisymmetric stretching vibration of $\mathrm{NO}_{3}{ }^{-}$in the residual samples. The antisymmetric stretching vibration and out-of-plane bending vibration of $\mathrm{CO}_{3}{ }^{2-}$ group in $\mathrm{CaCO}_{3}$ were at $857 \mathrm{~cm}^{-1}$ and $1481 \mathrm{~cm}^{-1}$. The peak at $3644 \mathrm{~cm}^{-1}$ was related to stretching vibration of $\mathrm{OH}^{-}$group in calcium hydroxide [15], which existed in the samples calcinated from temperature between $850^{\circ} \mathrm{C}$ and $1200^{\circ} \mathrm{C}$ for $8 \mathrm{~h}$. This fact was evidenced by the $\mathrm{OH}$ band (at $3644 \mathrm{~cm}^{-1}$ ), which was derived from $\mathrm{Ca}(\mathrm{OH})_{2}$ formed through absorption of water by $\mathrm{CaO}$ [18]. The disappearance of peak at $3644 \mathrm{~cm}^{-1}$ and bending vibration of $\mathrm{OH}^{-}$in $\mathrm{HA}$ at $635 \mathrm{~cm}^{-1}$ at the temperature above $1200^{\circ} \mathrm{C}$ indicated that calcium oxide and HA were obtained; thus they were consumed during reaction, which was too little to be detected. This phenomenon was consistent with characteristic diffraction peaks of calcium oxide in Figure 3, in which samples were calcinated from $850^{\circ} \mathrm{C}$ to $1200^{\circ} \mathrm{C}$, respectively.

The peak at $3672 \mathrm{~cm}^{-1}$ was derived from the stretching vibration of $\mathrm{OH}^{-}$group in $\mathrm{HA}$. This peak existed in these samples calcinated from $850^{\circ} \mathrm{C}$ to $1400^{\circ} \mathrm{C}$ for $8 \mathrm{~h}$. However, the peak intensity was gradually weakened and disappeared when the calcination temperature went up to $1450^{\circ} \mathrm{C}$. This indicated that the calcinated samples contained a some of HA under $1450^{\circ} \mathrm{C}$, which could be decomposed when calcination temperature was above $1450^{\circ} \mathrm{C}$. When calcination temperature went up to $1450^{\circ} \mathrm{C}$ and $1500^{\circ} \mathrm{C}$, the characteristic peaks of the TTCP at $454 \mathrm{~cm}^{-1}, 470 \mathrm{~cm}^{-1}, 501 \mathrm{~cm}^{-1}, 570 \mathrm{~cm}^{-1}$, $593 \mathrm{~cm}^{-1}, 601 \mathrm{~cm}^{-1}, 621 \mathrm{~cm}^{-1}$, and $930-1100 \mathrm{~cm}^{-1}$ appeared, corresponding to the vibration mode showed in Table 1.

Figure 6 displays FT-IR spectra of the calcination sample by different cooling methods. The three quenched samples 


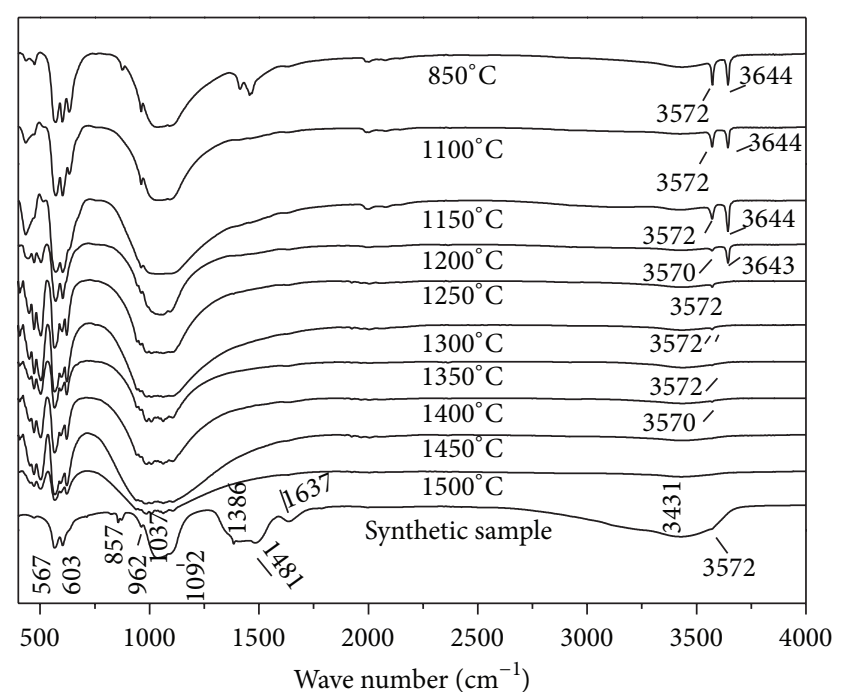

(a)

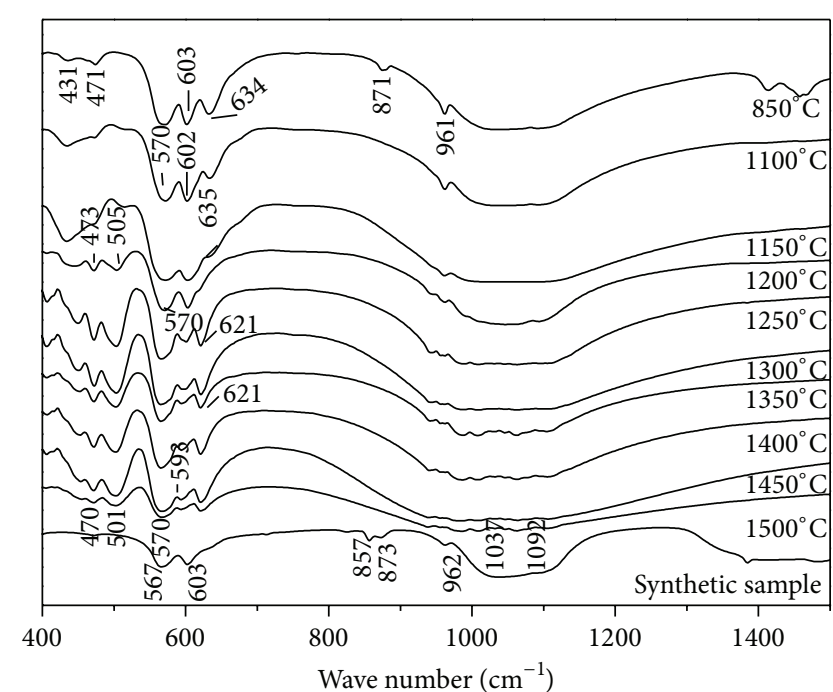

(b)

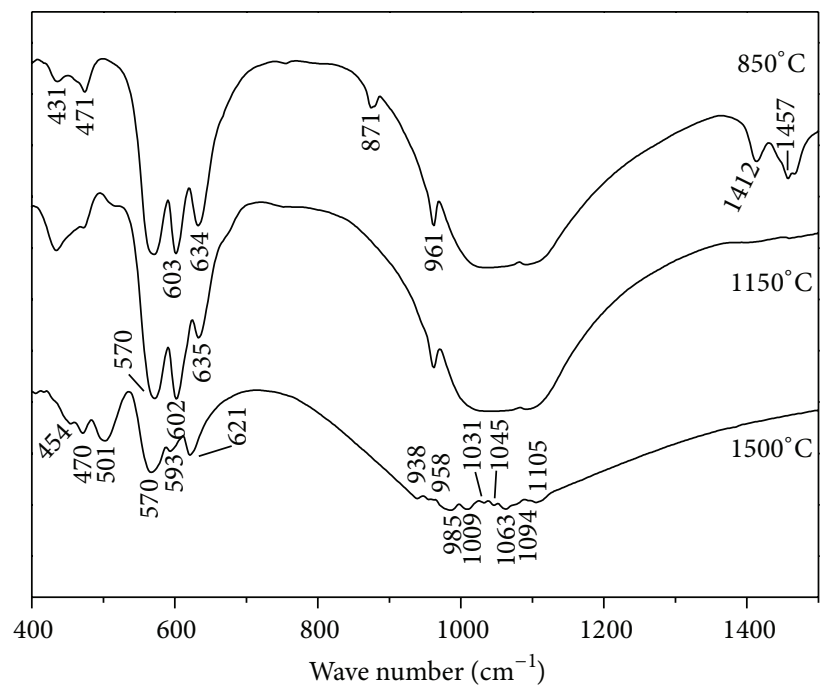

(c)

FIGURE 5: FT-IR spectra of synthetic samples in air-cooled quenching at various temperatures: full spectrum (a) and partial spectrum (b, c).

scarcely contained $\mathrm{OH}^{-}$stretching vibration, and only the quenched samples calcinated at $1400^{\circ} \mathrm{C}$ exhibited very weak $\mathrm{OH}^{-}$stretching vibration at ca. $3572 \mathrm{~cm}^{-1}$; these furnace cooling samples exhibited sharp peaks of $\mathrm{OH}^{-}$stretching vibration in $\mathrm{Ca}(\mathrm{OH})_{2}$ at $3643 \mathrm{~cm}^{-1}$; sharp peaks of $\mathrm{OH}^{-}$ stretching vibration in $\mathrm{HA}$ at $3572 \mathrm{~cm}^{-1}$ and $635 \mathrm{~cm}^{-1}$, and asymmetric stretching vibration of $\mathrm{CO}_{3}{ }^{2-}$ in $\mathrm{CaO}$, the calcium carbonate was derived from reaction of $\mathrm{Ca}(\mathrm{OH})_{2}$ and $\mathrm{CO}_{2}$ in the air. This result revealed that TTCP was decomposed into $\mathrm{HA}$ and $\mathrm{CaO}$ during the furnace cooling.

3.5. RS Analysis. Figure 7 shows the Raman spectra of synthetic samples by air-cooled quenching at various temperatures. As can be seen from Figures $7(\mathrm{~b})$ and $7(\mathrm{~g})$, the samples have the symmetric bending vibrations $v_{2}$ of $\mathrm{PO}_{4}{ }^{3-}$ at $429 \mathrm{~cm}^{-1}$, the asymmetric bending vibrations $\nu_{4}$ of $\mathrm{PO}_{4}{ }^{3-}$ at $586 \mathrm{~cm}^{-1}$, the symmetric stretching vibrations $\nu_{1}$ of $\mathrm{PO}_{4}{ }^{3-}$ about at $960 \mathrm{~cm}^{-1}$, and the symmetric stretching vibrations of $\mathrm{CO}_{3}{ }^{2-}$ at $1084 \mathrm{~cm}^{-1}$. Obviously, with calcination temperatures increasing from $1200^{\circ} \mathrm{C}$ to $1500^{\circ} \mathrm{C}$, the characteristic peaks of $\mathrm{PO}_{4}{ }^{3-}$ at $407 \mathrm{~cm}^{-1}, 448 \mathrm{~cm}^{-1}, 480 \mathrm{~cm}^{-1}, 586 \mathrm{~cm}^{-1}$, $958 \mathrm{~cm}^{-1}, 1042 \mathrm{~cm}^{-1}, 1075 \mathrm{~cm}^{-1}$, and $1095 \mathrm{~cm}^{-1}$ of $\mathrm{PO}_{4}{ }^{3-}$ were observed in the spectra of the calcinations samples. The $\mathrm{OH}^{-}$ stretching vibration at about $3570 \mathrm{~cm}^{-1}$ disappeared gradually, and the HA in the samples completely transformed into TTCP with the increase of calcination temperatures.

Figure $7(\mathrm{~g})$ shows the Raman spectra of the samples calcinated from $850^{\circ} \mathrm{C}$ to $1200^{\circ} \mathrm{C}$. The $\mathrm{OH}^{-}$Raman peaks from $\mathrm{HA}$ and $\mathrm{Ca}(\mathrm{OH})_{2}$ were clearly observed at $3571 \mathrm{~cm}^{-1}$ and $3619 \mathrm{~cm}^{-1}$, respectively. However, the two Raman peaks 
TABLE 1: Vibrational wave numbers $\left[\mathrm{cm}^{-1}\right]$ of samples.

\begin{tabular}{|c|c|c|c|}
\hline & $\begin{array}{c}\text { Raman } \\
\lambda_{0}=514.5 \mathrm{~nm} \\
\end{array}$ & $\begin{array}{c}\text { FT-IR } \\
\mathrm{KBr}\end{array}$ & Assignments \\
\hline \multirow{5}{*}{$\begin{array}{l}1400 \sim 1500^{\circ} \mathrm{C} \\
\times 8 \mathrm{~h}\end{array}$} & 327 & & Lattice modes \\
\hline & $390,408,448,481$ & $454,470,501$ & $\begin{array}{l}v_{2}, \mathrm{PO}_{4}^{3-} \text { bands in TTCP, symmetric } \\
\text { bending vibrations mode }\end{array}$ \\
\hline & $\begin{array}{c}555,565,577,598,608 \\
616\end{array}$ & $570,593,621$ & $\begin{array}{l}v_{4}, \mathrm{PO}_{4}^{3-} \text { bands in TTCP, asymmetric } \\
\text { bending vibrations mode }\end{array}$ \\
\hline & $941,948,957,963$ & 938,958 & $\begin{array}{l}v_{1}, \mathrm{PO}_{4}^{3-} \text { bands in TTCP, symmetric } \\
\text { stretching mode }\end{array}$ \\
\hline & $\begin{array}{l}992,1010,1027,1046 \\
1075,1095,1122,1135\end{array}$ & $\begin{array}{r}985,1009,1031,1045 \\
1063,1074,1094,1105\end{array}$ & $\begin{array}{l}v_{3}, \mathrm{PO}_{4}^{3-} \text { bands in TTCP, asymmetric } \\
\text { stretching mode }\end{array}$ \\
\hline \multirow{10}{*}{$\begin{array}{l}850-1150^{\circ} \mathrm{C} \\
\times 8 \mathrm{~h}\end{array}$} & \multirow{8}{*}{$\begin{array}{c}961 \\
1028,1046,1075,1123 \\
1085\end{array}$} & 431,471 & $v_{2}, \mathrm{PO}_{4}{ }^{3-}$ bands in $\mathrm{HA}$ \\
\hline & & 604 & $v_{4}, \mathrm{PO}_{4}{ }^{3-}$ bands in $\mathrm{HA}$ \\
\hline & & 634 & Vibrational mode of $\mathrm{OH}^{-}$ \\
\hline & & 871 & Out-of-plane bending vibrations of $\mathrm{CO}_{3}{ }^{2-}$ \\
\hline & & 961 & $v_{1}, \mathrm{PO}_{4}^{3-}$ bands in $\mathrm{HA}$ \\
\hline & & 1025,1091 & $v_{3}, \mathrm{PO}_{4}{ }^{3-}$ bands in $\mathrm{HA}$ \\
\hline & & & Symmetric stretching of $\mathrm{CO}_{3}^{2-}$ \\
\hline & & $1412,1452,1467$ & Asymmetric stretching of $\mathrm{CO}_{3}{ }^{2-}$ \\
\hline & 3572 & 3572 & $\mathrm{OH}^{-}$stretching vibration (in $\mathrm{HA}$ ) \\
\hline & 3619 & 3643 & $\mathrm{OH}^{-}$stretching vibration (in $\mathrm{Ca}(\mathrm{OH})_{2}$ ) \\
\hline
\end{tabular}

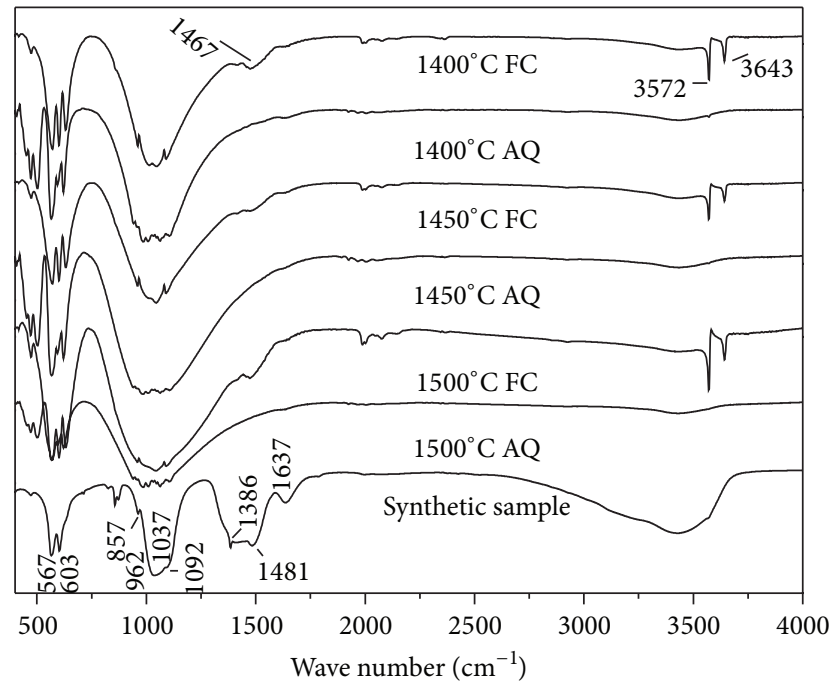

(a)

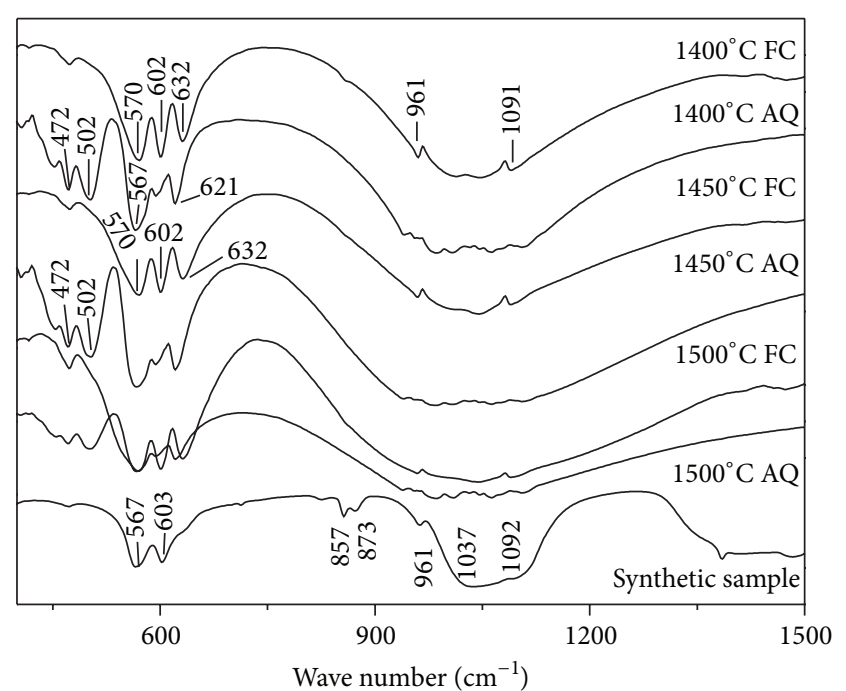

(b)

FIGURE 6: FT-IR spectra of the samples calcinated by different cooling methods: full spectrum (a) and partial spectrum (b). AQ indicates air quenching and FC indicates furnace cooling.

were gradually weakened with the temperature increasing from $850^{\circ} \mathrm{C}$ to $1200^{\circ} \mathrm{C}$; finally the Raman peak at $3619 \mathrm{~cm}^{-1}$ disappeared and only a strong $\mathrm{OH}^{-}$Raman peak of HA at $3571 \mathrm{~cm}^{-1}$ was retained when calcinated at $1250^{\circ} \mathrm{C}$. The peak at $3571 \mathrm{~cm}^{-1}$ also gradually decreased with the increasing temperature, which was almost invisible at $1400^{\circ} \mathrm{C}$, and completely disappeared when the temperature reached $1450^{\circ} \mathrm{C}$. The results suggested the formation of TTCP resulting from the reaction between $\mathrm{CaO}$ and $\mathrm{HA}$ with the calcination temperature increased, as given by the following equations:

$$
2 \mathrm{CaO}+\mathrm{Ca}_{10}\left(\mathrm{PO}_{4}\right)_{6}(\mathrm{OH})_{2} \longrightarrow 3 \mathrm{Ca}_{4} \mathrm{O}\left(\mathrm{PO}_{4}\right)_{2}+\mathrm{H}_{2} \mathrm{O}
$$

Equation (2) represented the existing reaction at $850^{\circ} \mathrm{C}$, in which the appearance of the $\mathrm{OH}^{-}$Raman peak in $\mathrm{Ca}(\mathrm{OH})_{2}$ was observed, which resulted from the reaction of calcium 


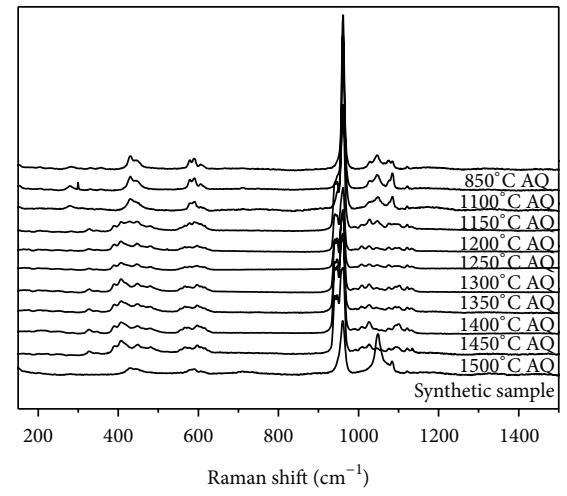

(a)

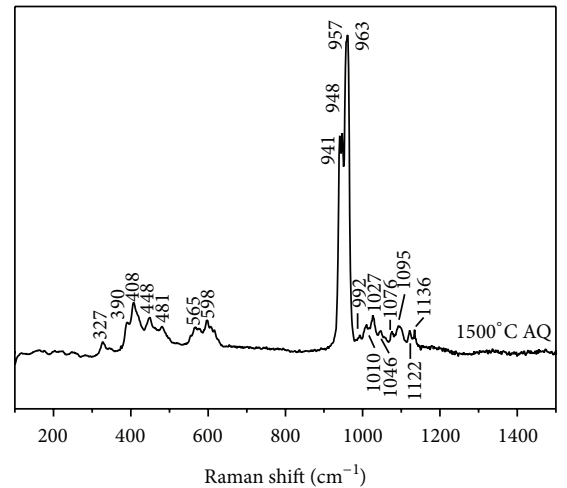

(c)

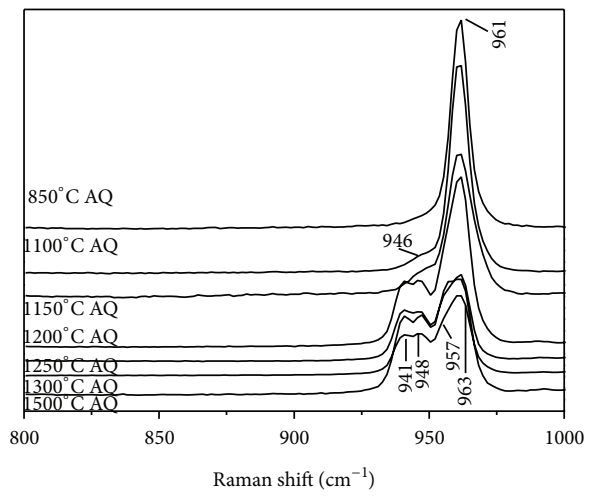

(e)

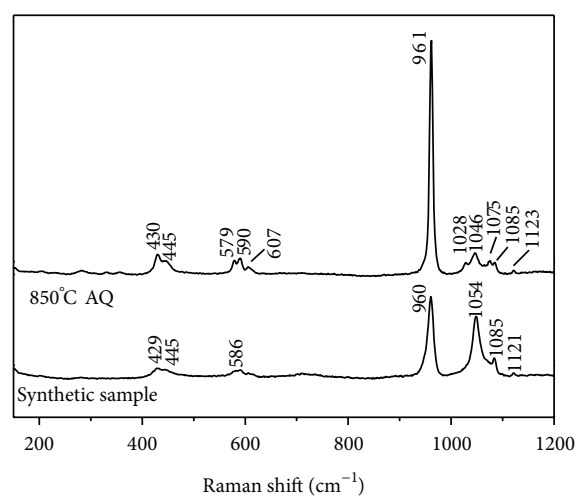

(b)

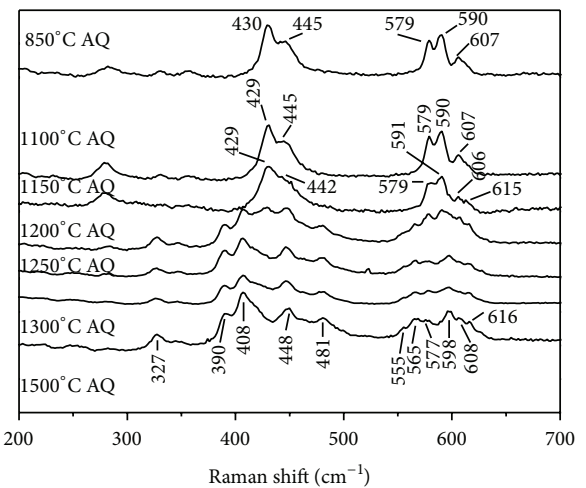

(d)

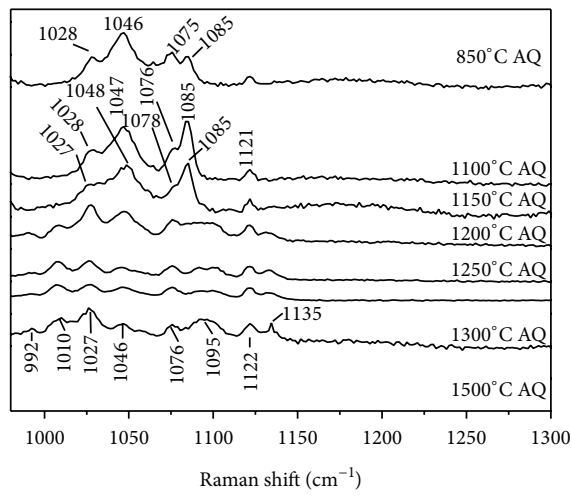

(f)

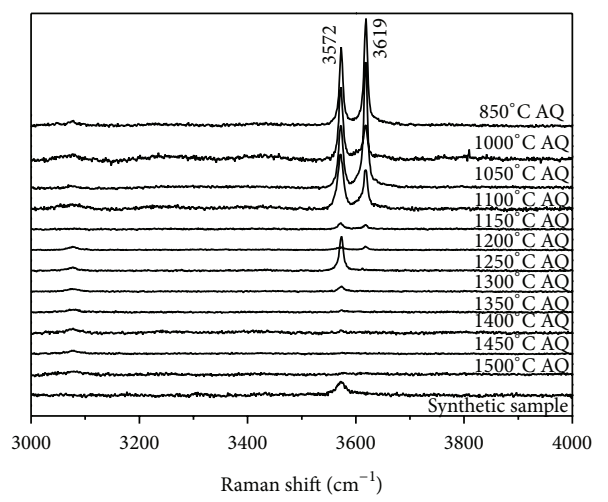

(g)

FIGURE 7: Raman spectra of synthetic samples by air-cooled quenching at various temperatures. 


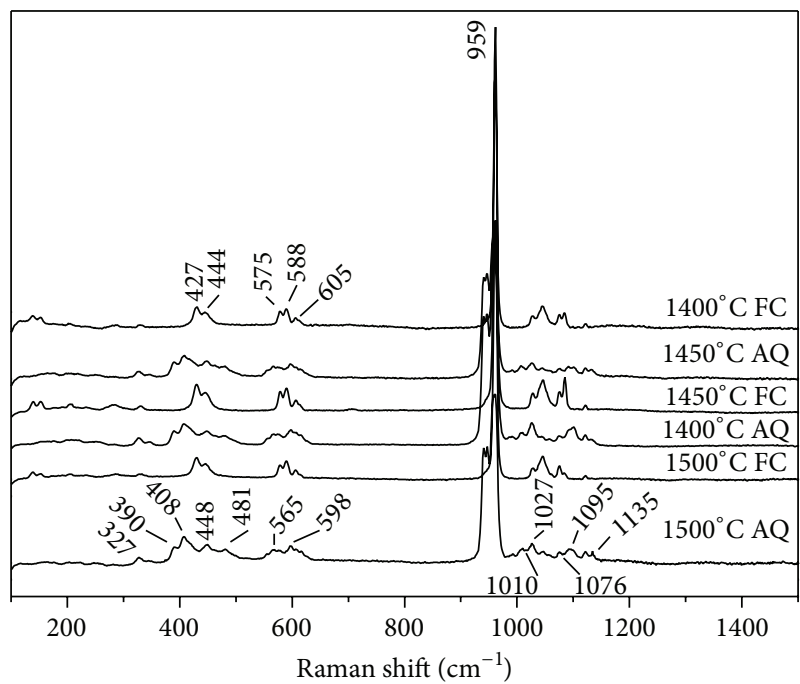

AQ: air quenching

FC: furnace cooling

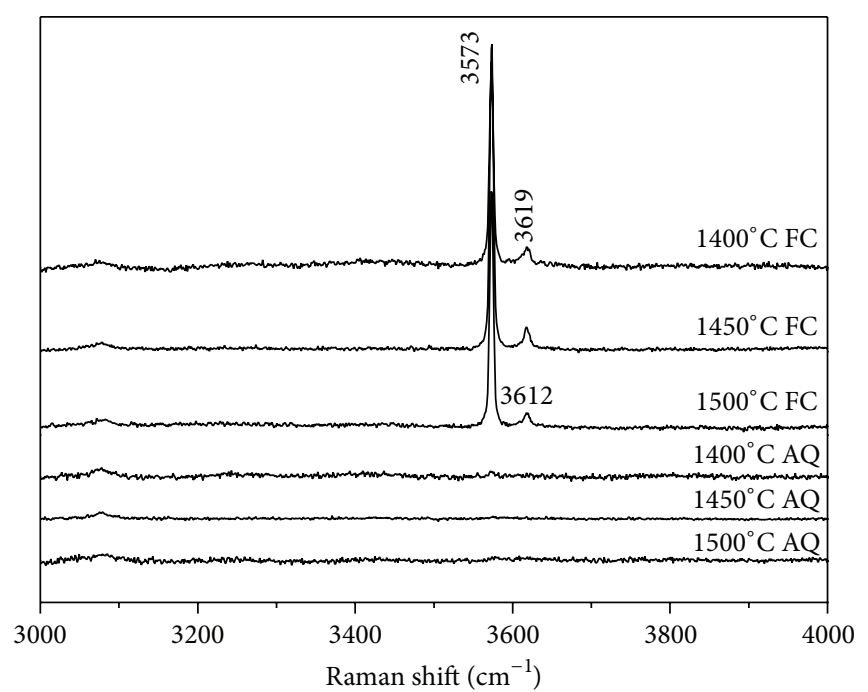

AQ: air quenching

FC: furnace cooling

(a)

(b)

FIGURE 8: Raman spectra of the samples calcinated by different cooling methods: Raman shift $100-1500 \mathrm{~cm}^{-1}$ (a) and Raman shift $3000-$ $4000 \mathrm{~cm}^{-1}(\mathrm{~b})$.

oxide and the water in the air. Equation (10) represented the reaction occurring when calcination temperature was up to $1150^{\circ} \mathrm{C}$ and above $1150^{\circ} \mathrm{C}$, which was evidenced by the change of Raman peak of the sample. As can be seen from Figure $7(\mathrm{~d})$, the symmetric bending vibration peaks $v_{2}$ of $\mathrm{PO}_{4}{ }^{3-}$ appeared at $389 \mathrm{~cm}^{-1}$ and $407 \mathrm{~cm}^{-1}$, and the original characteristic peak at $429 \mathrm{~cm}^{-1}$ was weakened at $1200^{\circ} \mathrm{C}$. The Raman peak at $429 \mathrm{~cm}^{-1}$ disappeared with the increase of temperature. Meanwhile, the Raman spectrum showed that the asymmetric bending vibrations peaks $v_{4}$ of $\mathrm{PO}_{4}{ }^{3-}$ at $578 \mathrm{~cm}^{-1}, 589 \mathrm{~cm}^{-1}$, and $606 \mathrm{~cm}^{-1}$ were splitted into six peaks at $555 \mathrm{~cm}^{-1}, 565 \mathrm{~cm}^{-1}, 576 \mathrm{~cm}^{-1}, 597 \mathrm{~cm}^{-1}, 608 \mathrm{~cm}^{-1}$, and $616 \mathrm{~cm}^{-1}$. As can be seen from Figure 7(e), the symmetric stretching vibration of $\mathrm{PO}_{4}{ }^{3-}\left(\nu_{1}\right)$ appeared at $946 \mathrm{~cm}^{-1}$ when it is at $1150^{\circ} \mathrm{C}$, then was splitted into four intense distinct peaks at $941 \mathrm{~cm}^{-1}, 948 \mathrm{~cm}^{-1}, 957 \mathrm{~cm}^{-1}$ and $963 \mathrm{~cm}^{-1}$ when it was increased to $1200^{\circ} \mathrm{C}$. Meanwhile, the appearance of lattice vibration Raman peak of TTCP at about $326 \mathrm{~cm}^{-1}$ in the calcination samples was confirmed. The reaction showed as (10) did not cease until it was up to $1450^{\circ} \mathrm{C}$, which can be demonstrated from the disappearance of $\mathrm{OH}^{-}$characteristic Raman peak at $1450^{\circ} \mathrm{C}$. In addition, the DTA curve in Figure 2 showed that the endothermic peaks of crystal structure transition began to occur at $1185^{\circ} \mathrm{C}$ in the sample, and it can be confirmed that the initial reaction temperature of (2) was between 1150 and $1200^{\circ} \mathrm{C}$.

Figure 8 is the Raman spectra patterns of synthetic samples calcinated at $1500^{\circ} \mathrm{C}, 1450^{\circ} \mathrm{C}$, and $1400^{\circ} \mathrm{C}$ and then cooled by two different methods, and the changes of Raman peaks are listed in Table 2. The Raman test showed that the furnace cooling samples led to the presence of the characteristic peak of $\mathrm{OH}^{-}$in $\mathrm{HA}$ at about $3573 \mathrm{~cm}^{-1}$ and characteristic peak of $\mathrm{OH}^{-}$in $\mathrm{Ca}(\mathrm{OH})_{2}$ at about $3619 \mathrm{~cm}^{-1}$. This result revealed that the sample was a mixture of $\mathrm{HA}$ and $\mathrm{CaO}$. Posset et al. [17] presented that the Raman peaks of $\mathrm{PO}_{4}{ }^{3-}$ symmetric stretching vibration $\nu_{1}$ were its characteristic peak. This peak, splitting or not, gave a major evidence for the difference between TTCP and HA. Only an intense distinct Raman peak in the range between 960 and $940 \mathrm{~cm}^{-1}$ and the spliting peak in the samples by furnace cooling could not be observed, indicating that TTCP can't be obtained by this cooling method. While the air-quenching samples exhibited four intense distinct peaks at this range, which demonstrated that TTCP was only product by air quenching.

3.6. Discussion. At present, common methods for the synthesis of TTCP are limited to solid-state reactions at high temperatures, based on powder mixtures of $\mathrm{CaCO}_{3}$ and dicalcium phosphate anhydrate $\left(\mathrm{CaHPO}_{4}\right)$ [19], in which the particle size of powder is in the micron level, with calcination temperature higher than $1450^{\circ} \mathrm{C}$. Though the reaction time was long enough for $6-12 \mathrm{~h}$, even up to $15-24 \mathrm{~h}[9,12,20]$, the products may still contain HA or OHA. Sargin et al. [15] reported several attempts to lower the required processing temperature for the TTCP synthesis using different combinations of various starting products. By varying the process temperatures, they showed that HA or TCP appeared as intermediate products at lower temperatures in all reactions. Although this reaction enabled the formation of TTCP even at $1200^{\circ} \mathrm{C}$, which was much lower than previous report, the purity was lower than that in the product obtained at $1350^{\circ} \mathrm{C}$. Jalota et al. [6] investigated $\mathrm{NH}_{4} \mathrm{H}_{2} \mathrm{PO}_{4}$ and $\mathrm{Ca}\left(\mathrm{CH}_{3} \mathrm{COO}\right)_{2} \cdot \mathrm{H}_{2} \mathrm{O}$ powders to further reduce the temperature required for the preparation of phase-pure TTCP. 
TABLE 2: Raman shift $\left[\mathrm{cm}^{-1}\right]$ of the calcinations samples by different cooling methods.

\begin{tabular}{|c|c|c|c|}
\hline & $\begin{array}{c}1400 \sim 1500^{\circ} \mathrm{C} \\
\times 8 \mathrm{~h} \text {, air quenching } \\
\end{array}$ & $\begin{array}{c}1400 \sim 1500^{\circ} \mathrm{C} \\
\times 8 \mathrm{~h} \text {, furnace cooling }\end{array}$ & Assignments \\
\hline \multirow{7}{*}{$\operatorname{Raman} \lambda_{0}=514.5 \mathrm{~nm}$} & 327 & & Lattice modes (TTCP) \\
\hline & $390,408,448,481$ & 427,444 & $\begin{array}{l}v_{2}, \mathrm{PO}_{4}^{3-} \text { bands, symmetric } \\
\text { bending vibrations mode }\end{array}$ \\
\hline & $555,565,577,598,608,616$ & $575,588,605$ & $\begin{array}{l}v_{4}, \mathrm{PO}_{4}{ }^{3-} \text { bands, asymmetric } \\
\text { bending vibrations mode }\end{array}$ \\
\hline & $941,948,957,963$ & 959 & $\begin{array}{l}v_{1}, \mathrm{PO}_{4}^{3-} \text { bands, symmetric } \\
\text { stretching mode }\end{array}$ \\
\hline & $\begin{array}{c}992,1010,1027,1046,1075 \\
1095,1122,1135\end{array}$ & $1026,1040,1072,1121$ & $\begin{array}{l}v_{3}, \mathrm{PO}_{4}{ }^{3-} \text { bands, asymmetric } \\
\text { stretching mode }\end{array}$ \\
\hline & & 3573 & $\mathrm{OH}^{-}$stretching vibration (in $\mathrm{HA}$ ) \\
\hline & & 3619 & $\begin{array}{l}\mathrm{OH}^{-} \text {stretching vibration (in } \\
\left.\mathrm{Ca}(\mathrm{OH})_{2}\right)\end{array}$ \\
\hline
\end{tabular}

However, the method was suitable only for the synthesis of HA-seeded TTCP powders, which were very sensitive and easily transformed into HA by mechanochemical activation [21]. Romeo and Fanovich [7] studied a solid-state reaction of $\mathrm{CaCO}_{3}$ and $\left(\mathrm{NH}_{4}\right)_{2} \mathrm{HPO}_{4}$ powders mixed with a $\mathrm{Ca} / \mathrm{P}$ ratio of 2 and ball-milled prior to thermal treatment. The smaller crystallite size of the milled powders increased the reactivity and significantly improved the purity of the final product.

It is well known that the driving force of calcination process comes from the decrease of systematic free energy, including increase in particles bonding areas and the total specific surface area, decrease in surface free energy, void volume and area reduction, the lattice distortion's elimination, and so forth. Due to the surface and interface effect, small size effect of nanoparticles, the driving force of grain growth is very big, decades or even one hundred times that of ordinary powder calcination process. So, this research shows that it is easy to obtain pure TTCP by using the wet method for synthesizing the mixture of nanoscale $\mathrm{HA}$ and calcium carbonate, followed by high temperature treatment.

According to [20], when the temperature was increased, the dehydration or decomposition of the prior formed $\mathrm{HA}$ will occur to form weak crystal oxyapatite $\left(\mathrm{Ca}_{10}\left(\mathrm{PO}_{4}\right)_{6}(\mathrm{OH})_{2-2 x} \mathrm{O}_{x} \square_{x}, \mathrm{OHA}\right)$ (equations (4), (11)), $x=0-l$, and $\square$ is oxygen vacancy [22]. As the thermodynamic metastable equilibrium phase [14], $\mathrm{Ca}_{l 0}\left(\mathrm{PO}_{4}\right)_{6} \mathrm{O}(x=l, \mathrm{OA})$ was less stable, easy to decompose into tricalcium phosphate $\left(\mathrm{Ca}_{3}\left(\mathrm{PO}_{4}\right)_{2}, \mathrm{TCP}\right)$ and $\mathrm{CaO}$ (equation (12)). When $\mathrm{CaO}$ is relatively excessive in the reaction system, TCP reacted with $\mathrm{CaO}$ rapidly with the extension of heat preservation time and TTCP was obtained (equation (9)). In this study, the synthetic mixture of nanoscale HA and CC crystals were calcinated at different temperature. Only characteristic diffraction peaks of $\mathrm{HA}$ and $\mathrm{CaO}$ were obtained at temperature lower than $1150^{\circ} \mathrm{C}$ as shown in Figure 3, in which the characteristic peak of TTCP appeared at $1200^{\circ} \mathrm{C}$. Meantime, the intensity of characteristic peaks from $\mathrm{HA}$ and $\mathrm{CaO}$ decreased; the characteristic peaks of $\mathrm{CaO}$ disappeared at $1250^{\circ} \mathrm{C}$, which might not be detected in the XRD pattern due to the sensitivity limitations of the instruments. However, as seen in Figure $7(\mathrm{~g})$, the strong Raman peaks of the $\mathrm{OH}^{-}$in HA showed that it still contained $\mathrm{HA}$ at $1250^{\circ} \mathrm{C}$. When the calcination temperature was higher than $1250^{\circ} \mathrm{C}$, the Raman peak intensities of $\mathrm{OH}^{-}$in $\mathrm{HA}$ gradually decreased, which however can be still distinguished at $1400^{\circ} \mathrm{C}$. The Raman peak of $\mathrm{OH}^{-}$disappeared at $1450^{\circ} \mathrm{C}$ and pure TTCP could be obtained in this case. The results showed that there was no $\alpha$-TCP or $\beta$-TCP in this experimental process, except for the intermediate products of $\mathrm{HA}$ and $\mathrm{CaO}$. When the temperature is higher than $1150^{\circ} \mathrm{C}$, the reaction between $\mathrm{HA}$ and $\mathrm{CaO}$ occurred directly and TTCP was formed (equation (10)):

$$
\begin{gathered}
\mathrm{Ca}_{10}\left(\mathrm{PO}_{4}\right)_{6}(\mathrm{OH})_{2} \longrightarrow \mathrm{Ca}_{10}\left(\mathrm{PO}_{4}\right)_{6} \mathrm{O}+\mathrm{H}_{2} \mathrm{O} \\
\mathrm{Ca}_{10}\left(\mathrm{PO}_{4}\right)_{6} \mathrm{O} \longrightarrow 3 \mathrm{Ca}_{3}\left(\mathrm{PO}_{4}\right)_{2}+\mathrm{CaO}
\end{gathered}
$$

In the preparation process of TTCP by high temperature solid-state reaction, cooling methods are of great importance. After heating, the samples must be rapidly quenched to room temperature in order to avoid the formation of undesired secondary phases such as $\mathrm{HA}, \mathrm{CaO}, \mathrm{CaCO}_{3}$, and $\beta$-TCP. Bohner [23] pointed out that TTCP could be obtained by a solid-state reaction at high temperatures (typically $1400^{\circ} \mathrm{C}$ ), usually between equimolar quantities of DCPD and $\mathrm{CaCO}_{3}$. This reaction should be carried out in a dry atmosphere of vacuum, or with rapid cooling to prevent TTCP to uptake of water from the environment which might lead to the formation of HA. Guo et al. [11, 20] investigated the effect of cooling rate on the purity of TTCP prepared by high temperature solid-state reaction. The results indicated that the purity of TTCP depended decisively on the cooling rate after TTCP was sintered at $1500^{\circ} \mathrm{C}$ for $15 \mathrm{~h}$. Quenching in air was propitious for the formation of pure TTCP, while cooling in furnace will cause the decomposition of TTCP and less TTCP obtained. It showed that cooling rate was a key to the synthesis of TTCP by solid-state reaction. 


\section{Conclusion}

The high-purity TTCP was prepared via coprecipitation-solid state reaction and calcination of $n-\mathrm{HA}$ and nano- $\mathrm{CaCO}_{3}$. In contrast, mixtures with good homogenization and weak crystallinity of nanocrystals were obtained using wet method reaction. In the latter preparation method, nano- $\mathrm{CaCO}_{3}$ and n-HA with high activity can be prepared after coprecipitation. The enhanced reactivity of the mixtures was related to both the loss of crystallinity of the reactants and the generation of defects at the surface of nanocrystals. It was established that the mixture of TTCP, HA, and $\mathrm{CaO}$ can be obtained by $8 \mathrm{~h}$ of heat treatment at temperature above $1200^{\circ} \mathrm{C}$, and the pure TTCP can be obtained if the temperature was above or equal to $1450^{\circ} \mathrm{C}$.

\section{Conflict of Interests}

The authors declare that there is no conflict of interests regarding the publication of this paper.

\section{Acknowledgments}

This work was financially supported by the National Natural Science Foundation of China (no. U1304820), the Education Department of Henan Province Basic Research Program (no. 13A430331), and Doctoral Program of Henan Polytechnic University (B2009-36).

\section{References}

[1] S. Takagi and L. C. Chow, "Formation of macropores in calcium phosphate cement implants," Journal of Materials Science: Materials in Medicine, vol. 12, no. 2, pp. 135-139, 2001.

[2] Y. Ueyama, K. Ishikawa, T. Mano et al., "Initial tissue response to anti-washout apatite cement in the rat palatal region: comparison with conventional apatite cement," Journal of Biomedical Materials Research, vol. 55, no. 4, pp. 652-660, 2001.

[3] C. Liu, H. Shao, F. Chen, and H. Zheng, "Effects of the granularity of raw materials on the hydration and hardening process of calcium phosphate cement," Biomaterials, vol. 24, no. 23, pp. 4103-4113, 2003.

[4] L. Medvecky, M. Giretova, and T. Sopcak, "Preparation and properties of tetracalcium phosphate-monetite biocement," Materials Letters, vol. 100, pp. 137-140, 2013.

[5] Y. Matsuya, S. Matsuya, J. M. Antonucci, S. Takagi, L. C. Chow, and A. Akamine, "Effect of powder grinding on hydroxyapatite formation in a polymeric calcium phosphate cement prepared from tetracalcium phosphate and poly(methyl vinyl ethermaleic acid)," Biomaterials, vol. 20, no. 7, pp. 691-697, 1999.

[6] S. Jalota, A. C. Tas, and S. B. Bhaduri, "Synthesis of HA-seeded TTCP $\left(\mathrm{Ca}_{4}\left(\mathrm{PO}_{4}\right)_{2} \mathrm{O}\right)$ powders at $1230^{\circ} \mathrm{C}$ from $\mathrm{Ca}\left(\mathrm{CH}_{3} \mathrm{COO}\right)$ $2 \cdot \mathrm{H}_{2} \mathrm{O}$ and $\mathrm{NH}_{4} \mathrm{H}_{2} \mathrm{PO}_{4}$," Journal of the American Ceramic Society, vol. 88, no. 12, pp. 3353-3360, 2005.

[7] H. E. Romeo and M. A. Fanovich, "Synthesis of tetracalcium phosphate from mechanochemically activated reactants and assessment as a component of bone cements," Journal of Materials Science: Materials in Medicine, vol. 19, no. 7, pp. 27512760, 2008.
[8] V. V. Samuskevich, N. K. Belous, and L. N. Samuskevich, "Sequence of solid-state transformations during heat treatment of $\mathrm{CaCO}_{3}+\mathrm{CaHPO}_{4}$ mixtures," Inorganic Materials, vol. 39, no. 5, pp. 520-524, 2003.

[9] J. E. Barralet, L. Grover, T. Gaunt, A. J. Wright, and I. R. Gibson, "Preparation of macroporous calcium phosphate cement tissue engineering scaffold," Biomaterials, vol. 23, no. 15, pp. 30633072, 2002.

[10] A. Hoshikawa, N. Fukui, A. Fukuda et al., "Quantitative analysis of the resorption and osteoconduction process of a calcium phosphate cement and its mechanical effect for screw fixation," Biomaterials, vol. 24, no. 27, pp. 4967-4975, 2003.

[11] D. Guo, K. Xu, and Y. Han, "Influence of cooling modes on purity of solid-state synthesized tetracalcium phosphate," Materials Science and Engineering B, vol. 116, no. 2, pp. 175-181, 2005.

[12] H. Dai, Y. Yan, Y. Wang, S. Li, and X. Jiang, "Study on preparation of tetracalcium phosphate powder," Bulletin of the Chinese Ceramic Society, vol. 21, p. 56, 2002 (Chinese).

[13] H. Aoki, Science and Medical Applications of Hydroxyapatite, Takayama Press System Center, JAAS, Tokyo, Japan, 1991.

[14] F.-H. Lin, C.-J. Liao, K.-S. Chen, and J.-S. Sun, “Thermal reconstruction behavior of the quenched hydroxyapatite powder during reheating in air," Materials Science and Engineering C, vol. 13, no. 1-2, pp. 97-104, 2000.

[15] Y. Sargin, M. Kizilyalli, C. Telli, and H. Güler, "A new method for the solid-state synthesis of tetracalcium phosphate, a dental cement: $\mathrm{x}$-ray powder diffraction and IR studies," Journal of the European Ceramic Society, vol. 17, no. 7, pp. 963-970, 1997.

[16] A. Jillavenkatesa and R. A. Condrate Sr., "The infrared and raman spectra of tetracalcium phosphate $\left(\mathrm{Ca}_{4} \mathrm{P}_{2} \mathrm{O}_{9}\right)$," Spectroscopy Letters, vol. 30, no. 8, pp. 1561-1570, 1997.

[17] U. Posset, E. Löcklin, R. Thull, and W. Kiefer, "Vibrational spectroscopic study of tetracalcium phosphate in pure polycrystalline form and as a constituent of a self-setting bone cement," Journal of Biomedical Materials Research, vol. 40, no. 4, pp. 640 645, 1998.

[18] A. Ślósarczyk, C. Paluszkiewicz, M. Gawlicki, and Z. Paszkiewicz, "The FTIR spectroscopy and QXRD studies of calcium phosphate based materials produced from the powder precursors with different $\mathrm{Ca} / \mathrm{P}$ ratios," Ceramics International, vol. 23, no. 4, pp. 297-304, 1997.

[19] C. Moseke and U. Gbureck, “Tetracalcium phosphate: synthesis, properties and biomedical applications," Acta Biomaterialia, vol. 6, no. 10, pp. 3815-3823, 2010.

[20] D. Guo, K. Xu, and Y. Han, "Phase transition of synthesizing tetra calcium phosphate in a solid-state reaction," Journal of Inorganic Materials, vol. 20, p. 317, 2005 (Chinese).

[21] U. Gbureck, J. E. Barralet, M. Hofmann, and R. Thull, "Mechanical activation of tetracalcium phosphate," Journal of the American Ceramic Society, vol. 87, no. 2, pp. 311-313, 2004.

[22] R. B. Heimann, H. V. Tran, and P. Hartmann, "Laser-Raman and Nuclear Magnetic Resonance (NMR) studies on plasmasprayed hydroxyapatite coatings: influence of bioinert bond coats on phase composition and resorption kinetics in simulated body fluid," Materialwissenschaft und Werkstofftechnik, vol. 34, no. 12, pp. 1163-1169, 2003.

[23] M. Bohner, "Calcium orthophosphates in medicine: from ceramics to calcium phosphate cements," Injury, vol. 31, no. 4, pp. D37-D47, 2000. 

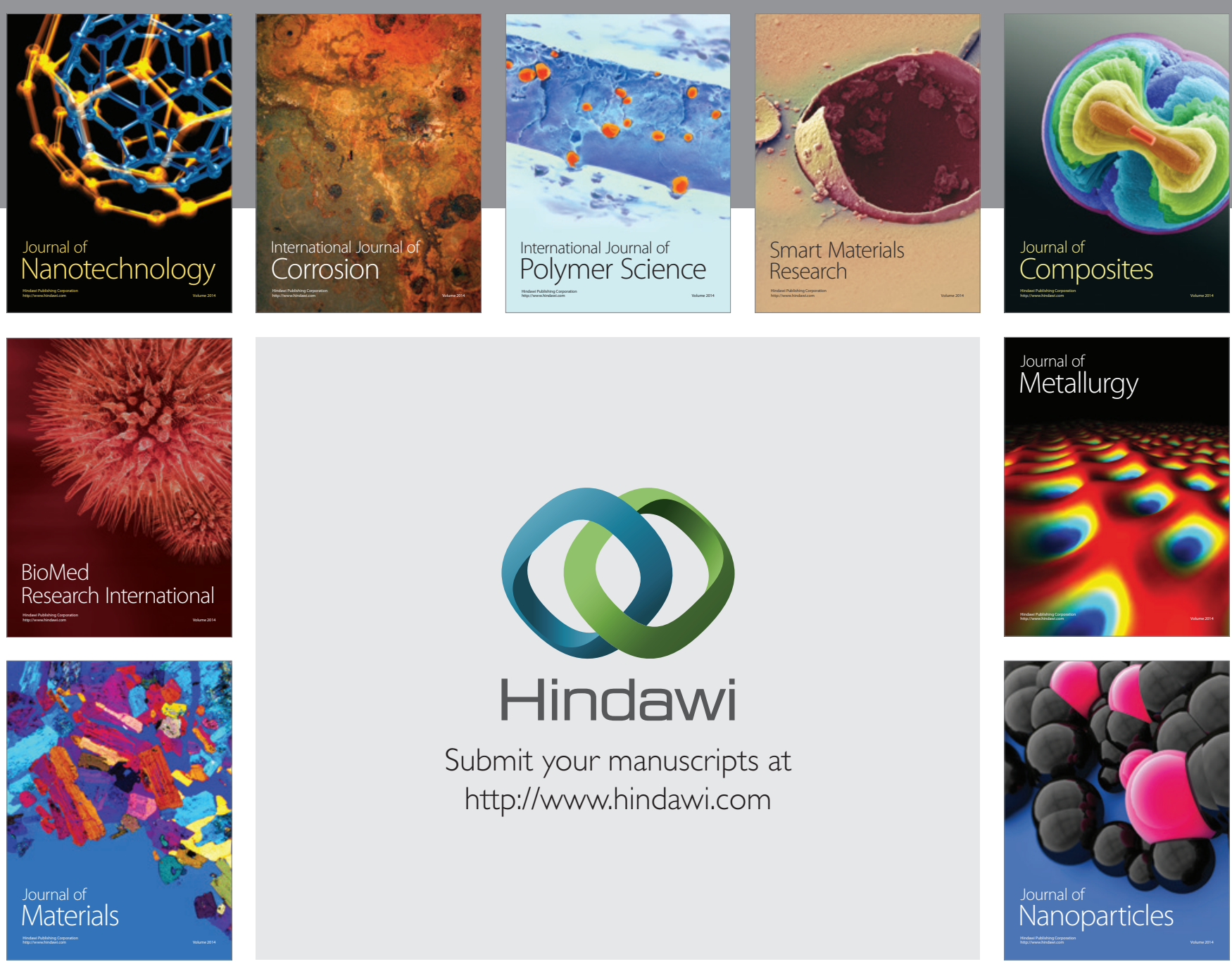

Submit your manuscripts at http://www.hindawi.com
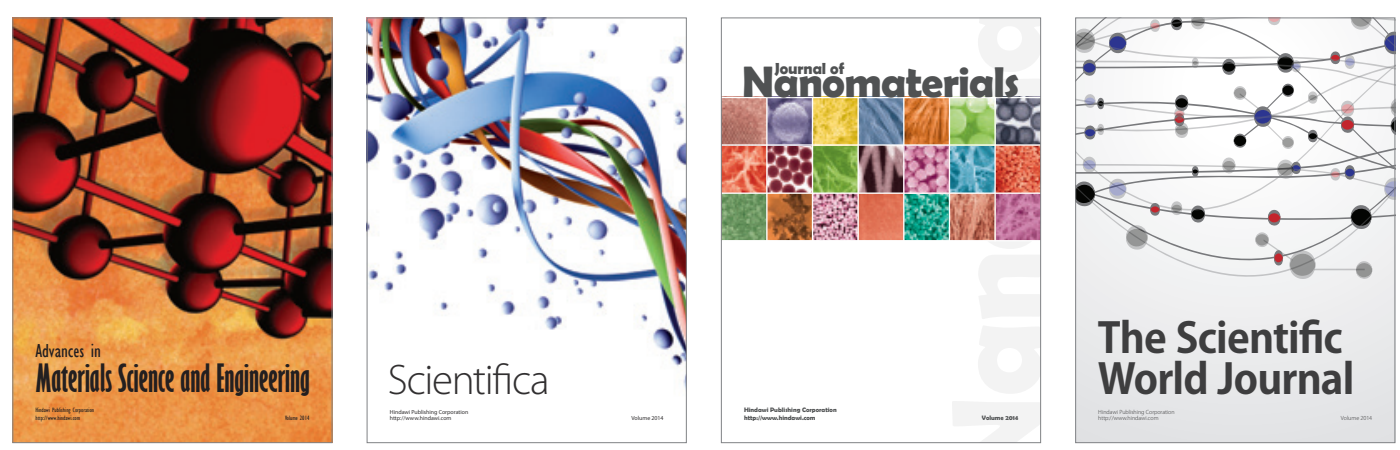

\section{The Scientific World Journal}
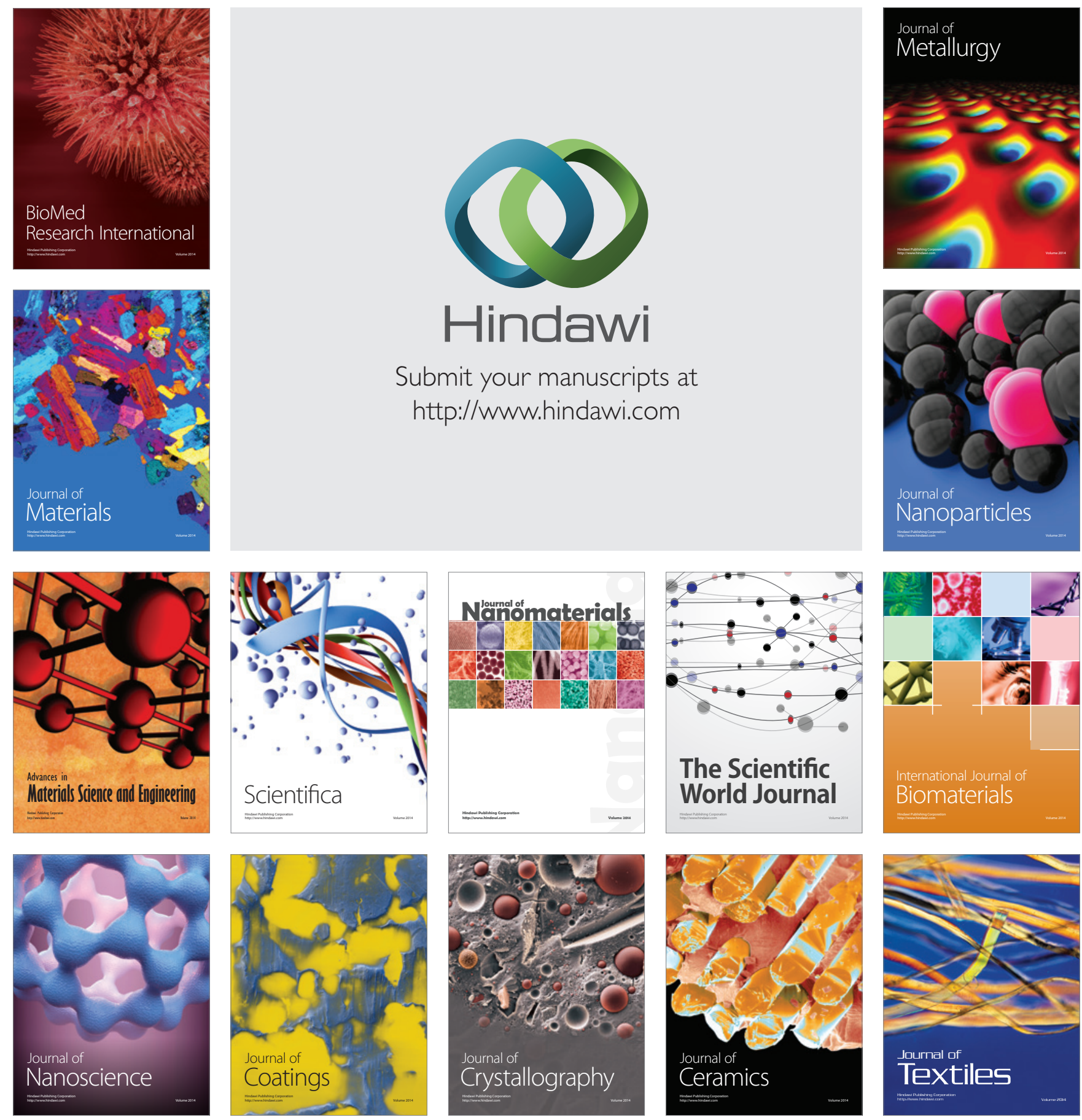